\title{
Initial characterization of novel beaked whale morbillivirus in Hawaiian cetaceans
}

\author{
Jessica M. Jacob ${ }^{1}$, Kristi L. West ${ }^{1}$, Gregg Levine ${ }^{2}$, Susan Sanchez ${ }^{3}$, \\ Brenda A. Jensen ${ }^{1, *}$ \\ ${ }^{1}$ College of Natural and Computational Sciences, Hawai'i Pacific University, 45-045 Kamehameha Highway, Kaneohe, \\ Hawai'i 96744, USA \\ ${ }^{2} 267$ S. Kalaheo Avenue, Kailua, Hawai'i 96734, USA \\ ${ }^{3}$ Department of Infectious Diseases, College of Veterinary Medicine, University of Georgia, Athens, Georgia 30602, USA
}

\begin{abstract}
Cetacean morbillivirus (CeMV) is a causative factor in epizootics that have resulted in thousands of deaths throughout the Atlantic and Mediterranean since 1987, but less is known of its presence and significance in the Pacific. The first case of CeMV reported in Hawai'i was in a Longman's beaked whale that stranded in 2010. The initial CeMV sequence from this individual indicated the possibility of a novel strain. To address this, archived samples from cetaceans that stranded in Hawai'i between 1997 and 2014 were screened for CeMV. The beaked whale morbillivirus (BWMV) was detected in 15 individuals representing 12 different species (24\% of Code 1 and 2 stranded cetaceans). The earliest detected case was a humpback whale that stranded in 1998. Sequence comparisons of a $2.2 \mathrm{~kb}$ sequence spanning the phosphoprotein $(\mathrm{P})$ and nucleocapsid (N) genes strongly suggest that the BWMV represents a novel strain of CeMV present in Hawai'i and the Central Pacific. In contrast to recently reported isolates from Brazil and Australia that may represent a distinct clade, BWMV appears to be more closely related to known strains of CeMV (dolphin morbillivirus; porpoise morbillivirus; and pilot whale morbillivirus). Detection rates with repeat sampling of positive lymph nodes were between 2 and $61 \%$, illustrating the extreme heterogeneity that can occur in affected tissues. Taken together, these results suggest that BWMV may be common and established in Hawaiian cetacean populations. BWMV will be important for understanding CeMV and health threats in the relatively understudied cetaceans of the Pacific.
\end{abstract}

KEY WORDS: Cetacean $\cdot$ Morbillivirus $\cdot$ Pacific $\cdot$ Hawai'i

\section{INTRODUCTION}

Cetacean morbillivirus (CeMV; Family Paramyxoviridae) is a member of the genus Morbillivirus, which includes 5 other virus species that affect mammals including the measles virus in humans, pestedes-petits-ruminants virus in ruminants, rinderpest virus in cattle, phocine distemper virus in the true seals, and canine distemper virus (CDV) in carnivores (Barrett et al. 1993, van de Bildt et al. 2005).
CeMV shares a common etiology with other morbilliviruses in that the immune system is the primary target, from which it can proliferate and spread to epithelial cells (reviewed in Van Bressem et al. 2014). Common secondary responses include pneumonia, meningoencephalitis, and hepatitis (Kennedy 1998, Reidarson et al. 1998, Taubenberger et al. 2000, Di Guardo et al. 2005). Classic pathological findings in cases of clinical CeMV include lesions in the lungs, lymph nodes, and brain. Multinucleated cells (syn- 
cytia) and intranuclear inclusion bodies are often noted microscopically in these organ systems (Kennedy 1998, Taubenberger et al. 2000, Di Guardo et al. 2005).

CeMV has caused many epizootics in the Atlantic Ocean, Gulf of Mexico, Mediterranean Sea, and adjacent seas (Visser et al. 1993, Kennedy 1998, Bossart et al. 2010, Bellière et al. 2011a). The first known CeMV epizootic occurred in 1987-1988 on the east coast of the USA and killed over $50 \%$ of the in-shore Atlantic bottlenose dolphin Tursiops truncatus population (Lipscomb et al. 1994, Krafft et al. 1995, Taubenberger et al. 1996). Another major event on the Spanish coast of the Mediterranean Sea in 1990 killed thousands of striped dolphins Stenella coeruleoalba (Barrett et al. 1993, Blixenkrone-Møller et al. 1994, Bellière et al. 2011b). Between 2006 and 2007, CeMV was detected in 9 long-finned pilot whales Globicephala melas that stranded along the southern Spanish Mediterranean coast and Balearic Islands (Fernández et al. 2008). More recently, in 2013 CeMV was detected in 24 stranded cetaceans of various species along the Tyrrhenian coast of Italy (Casalone et al. 2014), while another outbreak in 2013 along the east coast of the USA killed hundreds of bottlenose dolphins (Brown et al. 2014).

While isolated cases of CeMV continue to be diagnosed throughout the Pacific Ocean, it has not caused any obvious epizootics in this region. The first documented cases of CeMV in the Pacific were in 3 common dolphins Delphinus delphis that stranded on the California coast of the USA between 1995 and 1997 (Reidarson et al. 1998). In 1998, a Pacific striped dolphin Lagenorhynchus obliquidens stranded with CeMV on the coast of Japan (Uchida et al. 1999). In the Hawaiian Islands, the first diagnosed case of CeMV was in a Longman's beaked whale Indopacetus pacificus that stranded in 2010 on the island of Maui, followed soon after by a Blainville's beaked whale Mesoplodon densirostris (West et al. 2013), and a neonate sperm whale Physeter macrocephalus in 2011 (West et al. 2015).

Molecular characterization has revealed information about CeMV structure and the 3 commonly recognized strains. The CeMV genome is composed of 6 different genes: 5'-N-P-M-F-H-L-3'. The nucleocapsid $(\mathrm{N})$ gene and the phosphoprotein $(\mathrm{P})$ gene have been particularly important for characterizing CeMV. The P-gene is a highly conserved structural protein that can be used to identify morbillivirus species in various mammals (Barrett et al. 1993, Visser et al. 1993, Bolt et al. 1995), while the N-gene that encodes the $\mathrm{N}$ protein is less conserved across mor- billivirus species, and can be used to characterize and distinguish between different morbillivirus species and strains (Diallo et al. 1994). The porpoise morbillivirus (PMV) strain was associated with several epizootics in the Atlantic Ocean in the 1980s and 1990s (Kennedy et al. 1988), while dolphin morbillivirus (DMV) has caused outbreaks in the Atlantic Ocean and the Mediterranean Sea from the 1980s to the present day (Blixenkrone-Møller et al. 1994). In contrast, pilot whale morbillivirus (PWMV) has not been associated with any major outbreaks (Taubenberger et al. 2000).

The discovery of CeMV in the Longman's beaked whale demonstrated the need to more closely examine CeMV in Hawaiian cetaceans, as well as to address the hypothesis that the beaked whale morbillivirus (BWMV) represents a novel strain of CeMV in the Pacific. The purpose of this research was threefold: (1) to survey the archive of stranded Hawaiian cetacean tissues for CeMV using reverse transcription polymerase chain reaction (RT-PCR) in order to amplify the P-gene region, (2) to characterize the Hawaiian CeMV isolates by sequencing the P- and $\mathrm{N}$-gene regions using direct sequencing, and (3) to examine the heterogeneous distribution of CeMV in tissues. This retroactive survey is the first comprehensive examination of CeMV occurrence in Hawaiian cetaceans.

\section{MATERIALS AND METHODS}

\section{Sample collection}

Since 2006, the Hawai'i Pacific University (HPU) Marine Mammal Stranding Team has partnered with the National Oceanographic and Atmospheric Administration (NOAA) to conduct cause of death investigations in cetaceans that strand in the Hawaiian Islands and the Pacific Islands Region (PIR). These investigations include gross pathology, histopathology, and other diagnostics as indicated and as feasible. This study examined 62 cetaceans that stranded between 1997 and 2014; 58 in the main Hawaiian Islands and 4 in the PIR (see Fig. 1). Individuals were characterized as either Code 1 (first observed alive and sampled soon after death), or Code 2 (freshly dead with little decomposition of organs) as described by Geraci \& Lounsbury (1993). Pending availability, between 3 and 25 tissues were examined, including brain (cerebrum and cerebellum), spleen, liver, various lymph nodes, lung (left and right), kidney (left and right), and blood. Beaked 
whale muscle, blubber, and skin were screened to assess the feasibility of identifying CeMV in skin and blubber biopsies. Amniotic fluid, uterus, and ovaries from a pregnant striped dolphin were also examined.

\section{RNA extraction, quantification, and quality control}

Tissues designated for RNA isolation were maintained between -60 and $-80^{\circ} \mathrm{C}$. Beginning in 2011, samples were also preserved in RNA Later (\#67106, Qiagen) when dry ice was not available. Sub-samples $\left(10 \mathrm{~mm}^{3}\right)$ were processed using the SV Total RNA Isolation System Kit (\#Z3100, Promega) following the manufacturer's instructions and recommendations for maximum extraction efficiency. All RNA and PCR procedures occurred under PCR sterile conditions.

RNA was quantified by UV spectroscopy in a SmartSpec Plus UV Spectrophotometer (BioRad). Total RNA quality was assessed by RNA gels: $1.2 \%$ sterile agarose with $1 \times 3$-( $\mathrm{N}$-morpholino) propanesulfonic acid buffer, $2.88 \mathrm{ml}$ of $37 \%$ formaldehyde, and $8 \mu \mathrm{l}$ of ethidium bromide (Masek et al. 2005). RNA samples were prepared by combining $10 \mu \mathrm{l}$ of RNA with $10 \mu \mathrm{l}$ of formaldehyde sample buffer (Lonza), incubated at $65^{\circ} \mathrm{C}$ for $5 \mathrm{~min}$, and cooled on ice for $1 \mathrm{~min}$ prior to loading. The prominence of ribosomal RNA subunits and the relative distribution of RNA relative to the subunits were used to qualitatively assess the RNA. Well-defined RNA subunits indicate high quality RNA that is not severely degraded.

\section{Characterization of CeMV isolates using $\mathrm{P}$ - and $\mathrm{N}$-genes}

Approximately 100 to 1000 ng total RNA was used as a template for cDNA synthesis with Moloney Murine Leukemia Virus Reverse Transcriptase (MMLVRT) (\#M1701, Promega) and random primers (\#C1181, Promega) according to the manufacturer's instructions. PCR was used to amplify a 429 bp P-gene fragment from cDNA. A total of $1 \mu \mathrm{M}$ of the primers P429forward and P429-reverse (Table 1) (Barrett et al. 1993) and $2 \mu \mathrm{l}$ cDNA were used with Go Taq Hot Start Green PCR master mix (\#M5123, Promega). PCR products were confirmed using standard gel electrophoresis in a $1 \%$ agarose gel containing ethidium bromide. A positive CeMV test generated a distinct band around $429 \mathrm{bp}$ in length on the gel. The absence of a band around $429 \mathrm{bp}$ indicated that CeMV was not detected. Amplification of a $322 \mathrm{bp}$ fragment of the housekeeping gene $\beta$-actin was used as a positive control for RNA extraction and reverse transcription (Table 1) (Jensen 2000). The positive PCR control consisted of template cDNA from one of several tissues from the Longman's beaked whale that was confirmed positive by the Athens Diagnostic Laboratory (College of Veterinary Medicine, University of Georgia, Athens, GA) (West et al. 2013). Replacement of the cDNA template with nuclease-free water confirmed that cross-contamination did not occur during sample preparation. Each positive tissue was confirmed by an additional independent analysis of the cDNA that included a random selection of experimental tissues plus the positive and negative controls.

Table 1. Primers used to screen and characterize cetacean morbillivirus (CeMV) P- and N-genes in stranded Hawaiian cetaceans. Primer pairs are listed, and the target nucleotide annealing location is included in the name

\begin{tabular}{|c|c|c|c|}
\hline Target & Primer pair & Sequence $\left(5^{\prime}-3^{\prime}\right)$ & Product length (bp) \\
\hline P-gene & $\begin{array}{l}\text { P429F } \\
\text { P429R }\end{array}$ & $\begin{array}{l}\text { ATG TTT ATG ATC ACA GCG GT } \\
\text { ATT GGG TTG CAC CAC TTG TC }\end{array}$ & 429 \\
\hline N- and P-genes & $\begin{array}{l}\text { MVJJP429R } \\
\text { MVJJ630RRC }\end{array}$ & $\begin{array}{l}\text { GGG TTG CAC CAC CTG TCA A } \\
\text { GCA TCT ATT CTT GCA CAA ATT T }\end{array}$ & 1949 \\
\hline N- and P-genes & $\begin{array}{l}\text { MVJJ391F } \\
\text { MVJJ630R }\end{array}$ & $\begin{array}{l}\text { CAG ATG TCA GCA TCA GAT TAG TTG } \\
\text { AAA TTT GTG CAA GAA TAG ATG C }\end{array}$ & 240 \\
\hline N- and P-genes & $\begin{array}{l}\text { MVJJ749F } \\
\text { MVJJ1518R }\end{array}$ & $\begin{array}{l}\text { ATG GTT GGA TGC TGT GAG AAA TC } \\
\text { GAG TGT CTT TGC TGA GAG TCG T }\end{array}$ & 770 \\
\hline N- and P-genes & $\begin{array}{l}\text { MVJJ391F } \\
\text { MVJJ1036R }\end{array}$ & $\begin{array}{l}\text { CAG ATG TCA GCA TCA GAT TAG TTG } \\
\text { GAC GTC TCG CCC ATC TGT T }\end{array}$ & 646 \\
\hline N- and P-genes & $\begin{array}{l}\text { MVJJ749F } \\
\text { MVJJ1036R }\end{array}$ & $\begin{array}{l}\text { ATG GTT GGA TGC TGT GAG AAA TC } \\
\text { GAC GTC TCG CCC ATC TGT T }\end{array}$ & 288 \\
\hline$\beta$-actin gene & $\begin{array}{l}\text { BelActin_D1 } \\
\text { BelActin_D1 }\end{array}$ & $\begin{array}{l}\text { AGA GCA AGA GAG GCA TCC TG } \\
\text { TAG ATA GGC ACG TGT GGG }\end{array}$ & 322 \\
\hline
\end{tabular}


Five additional primer pairs were designed using Primer 3 and MacVector software to target the Ngene and additional P-gene regions based on DMV sequence (GenBank acc. no. AJ608288) (Table 1). All bands of expected size were excised and purified using the Wizard SV Gel and PCR Clean-Up System (\#A9282, Promega) and prepared in duplicate for forward and reverse direct sequencing at the University of Hawai'i at Manoa's Advanced Studies of Genomics, Proteomics, and Bioinformatics (ASGPB) laboratory. The number of independent sequence reads contributing to the consensus sequence for individual isolates ranged from 5 to 33, depending on the number of tissues in which CeMV was detected.

Percent similarity tables and phylogenetic trees were generated using MacVector Multiple Sequence Analysis ClustalW software. Partial P-gene sequences are available for 2 other CeMV strains (DMV and PWMV) and 2 regional isolates (Southwest Atlantic Brazilian [SWAt] and Swan River from Australia). Sequence similarities to DMV, PWMV, SWAt, and Swan River isolates were calculated in 2 ways. First, nucleotide similarities were calculated based on the $216 \mathrm{bp}$ P-gene sequence common to all individuals. Second, each animal's consensus sequence (of varying lengths) was compared to the full length DMV sequence using the nucleotide basic local alignment search tool (BLAST N) algorithm. N-gene nucleotide similarities among the Hawaiian CeMV, DMV, PWMV, PMV, and Swan River isolates were based on $188 \mathrm{bp}$, the length of the Swan River consensus sequence. In order to avoid bias from longer sequences, percent nucleotide similarities among CeMV sequences were based on the longest continuous sequence common to all. The $\mathrm{N}$ - and P-gene sequence similarities were examined using the neighbor-joining tree method to compare Hawaiian CeMV, DMV, PMV, PWMV, SWAt, and Swan River, with CDV as an outgroup. Nucleotide differences were calculated by Tamura-Nei, with gaps distributed proportionally and no gamma correction.

\section{Heterogeneity of CeMV}

CeMV distribution throughout tissues was examined in lymph nodes from KW2010012 (Blainville's beaked whale Mesoplodon densirostris) and KW20 11021 (rough-toothed dolphin Steno bredanensis). Each lymph node was sub-sampled into $100 \mathrm{~mm}^{3}$ tissue blocks ( $\mathrm{n}=24,6$, and 9 for $M$. densirostris mediastinal lymph, $M$. densirostris anal lymph, and $S$. bredanensis anal lymph, respectively). Two $10 \mathrm{~mm}^{3}$ sub-samples of each tissue block were screened for morbillivirus by RT-PCR as described above. The detection rate, defined as the ability to detect CeMV across lymph node sub-sections, was used to report the ability to amplify CeMV (Katayama et al. 1998, Shin et al. 2004). The detection rate was calculated for each individual lymph node, for interior sub-samples (edge and middle cuts from sub-samples that did not touch the end of the lymph node), and for exterior sub-samples (edge and middle cuts from sub-samples that included the end of the lymph node).

\section{RESULTS}

\section{RT-PCR amplification of the CeMV P-gene}

Suites of tissues ( 3 to 25 ind $^{-1}$ ) collected from Code 1 and Code 2 cetaceans stranded in Hawai'i were screened using PCR targeting the CeMV P-gene. CeMV was detected in 15 animals out of a total of 58 stranded Hawaiian cetaceans examined. CeMV was not detected in the 4 animals from outside Hawai'i in the PIR: 2 Cuvier's beaked whales Ziphius cavirostris from Saipan, 1 spotted dolphin Stenella attenuata from Guam, and 1 melon-headed whale Peponocephala electra from Kosrae, Micronesia.

In addition to the Longman's beaked whale, Blainville's beaked whale (West et al. 2013) and sperm whale (West et al. 2015) that had been reported previously, CeMV was detected in 12 additional Hawaiian cetaceans representing 9 additional species: Cuvier's beaked whale (1/1), humpback whale Megaptera novaeangliae (1/7), pygmy sperm whale Kogia breviceps (1/1), rough-toothed dolphin (1/2), spinner dolphin Stenella longirostris (3/16), spotted dolphin (1/2), striped dolphin (2/11), bottlenose dolphin (1/3), and Risso's dolphin Grampus griseus (1/1) (Table 2, Fig. 1). The 6 Hawaiian species in which CeMV was not detected included the dwarf sperm whale Kogia sima (0/3), false killer whale Pseudorca crassidens (0/2), killer whale Orcinus orca $(0 / 1)$, melon-headed whale $(0 / 3)$, pygmy killer whale Feresa attenuata (0/1), and short-finned pilot whale Globicephala macrorhynchus (0/1).

CeMV was most frequently detected in lymph node (13/337), followed by brain (cerebrum 6/48, cerebellum 2/49, unknown brain 0/18), lung (5/130), liver (4/69), spleen (3/68), kidney (1/116), and blood $(1 / 5)$ (Table 3$)$. CeMV was not detected in muscle $(0 / 3)$, blubber $(0 / 3)$, skin $(0 / 3)$, uterus $(0 / 1)$, ovary $(0 / 2)$, or amniotic fluid (0/1) (Table 3). CeMV was detected in more females (9/24) than males (6/38) (Table 2). CeMV was most often detected in adults 


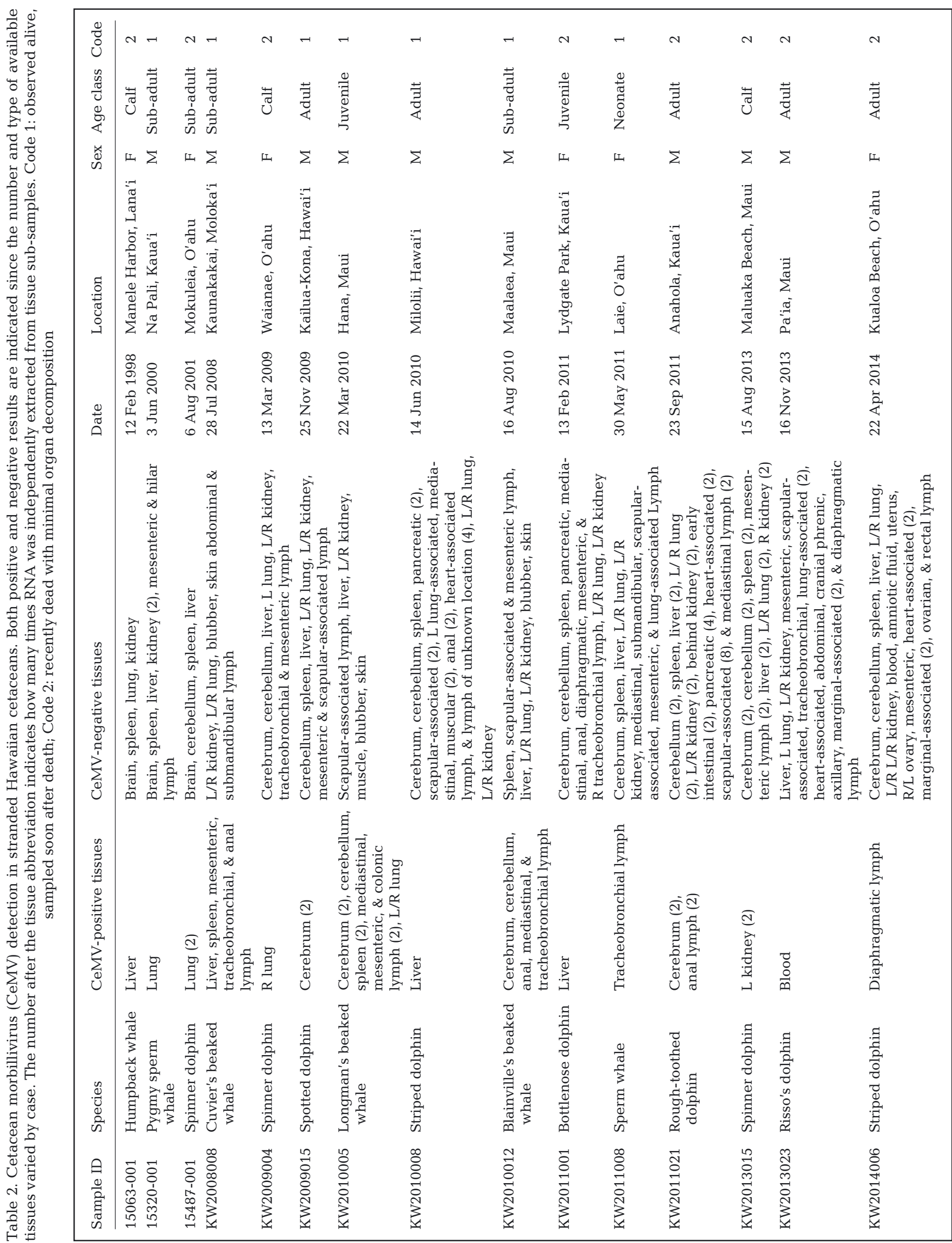




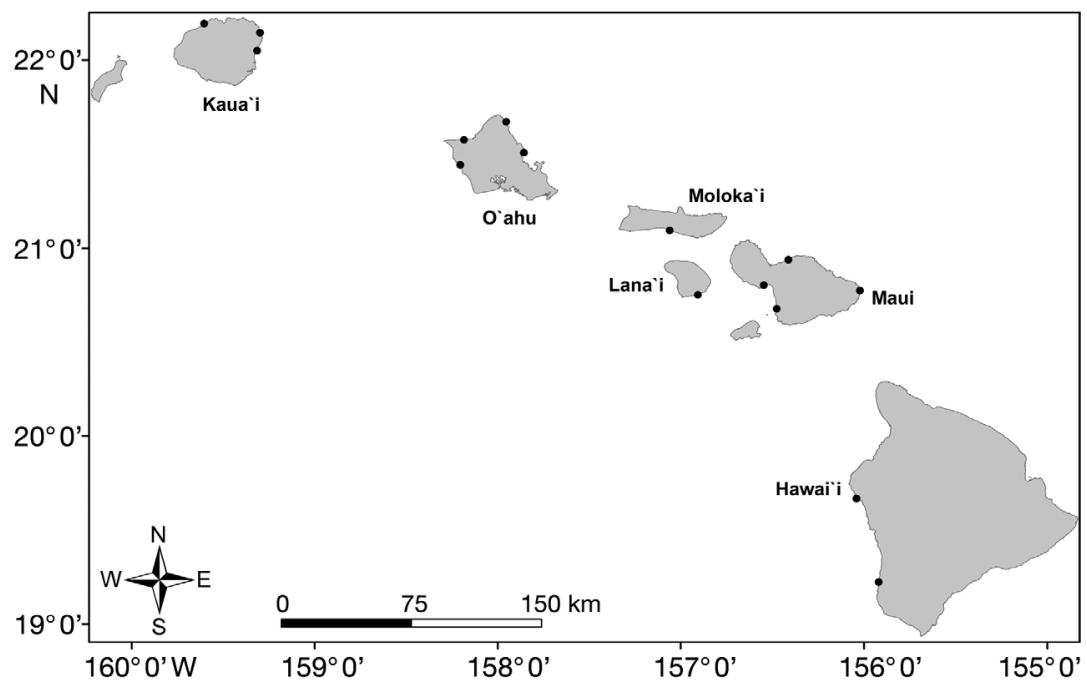

Fig. 1. Stranding locations of cetaceans with beaked whale cetacean morbillivirus (BWMV) in Hawai'i. Each black dot represents the location of a stranded cetacean in which BWMV was detected. The figure was created using ArcMap v.10.2.1 (ESRI)

$(5 / 26)$ and sub-adults $(4 / 12)$, followed by calves $(3 / 17)$, juveniles $(2 / 2)$, and neonates $(1 / 3)$, but CeMV was never detected in yearlings (0/2) (Table 2). CeMV was detected in more Code 2 (fresh dead) animals (8/33), than Code 1 (stranded alive) animals (7/29) (Table 2).

\section{Characterization of CeMV isolates using $\mathrm{P}$ - and N-genes}

The P-gene sequence was obtained for all animals except the spotted dolphin (KW2009015), despite repeated attempts. The nucleotide similarity between P-gene consensus sequences from individual stranded cetaceans ranged from 97.2 to $100 \%$ (Table 4). The $216 \mathrm{bp} \mathrm{P-}$ gene sequence common to all individuals was between 80.6 and $83.8 \%$ similar to PWMV and DMV, respectively (Table 4). Using the BLAST N algorithm to compare the full DMV sequence, Hawaiian isolates of the Pgene were 83 to $88 \%$ similar to DMV.

Multiple overlapping sequences across the $\mathrm{N}$ - and P-genes were aligned to generate a $2180 \mathrm{bp}$ consensus segment of the Hawaiian CeMV genome. This sequence spans the majority of the CeMV N- and Pgenes. The P-gene region consensus was generated using the 14 individuals in which CeMV was detected and sequenced. Ultimately, 3 individual cases and associated organs were the most useful for characterization of the N-gene and additional P-gene regions: KW2010005 (Longman's beaked whale) mediastinal lymph, cerebrum, and right lung; 15320 (pygmy sperm whale) lung (GenBank acc. no. KM975650); and KW2010012 (Blainville's beaked whale) cerebrum (GenBank acc. no. KM975651). Because the Longman's beaked whale sequence is 98 to $100 \%$ identical to each Hawaiian isolate at each comparable locus (Table 4), and is identical to the Hawaiian consensus, the Longman's BWMV (Gen-

Table 3. Cetacean morbillivirus (CeMV) detection in various tissues from stranded cetaceans. A total of 853 archived tissue samples were screened; CeMV was detected in 35 tissue samples from 15 animals

\begin{tabular}{|c|c|c|c|c|c|c|}
\hline Tissue type & $\begin{array}{c}\text { No. of ind. } \\
\text { with archived } \\
\text { tissue }(n=62)\end{array}$ & $\begin{array}{l}\text { CeMV-positive } \\
\text { With archived } \\
\text { tissue }\end{array}$ & $\begin{array}{l}\text { ind. }(\mathrm{n}=15) \\
\text { With positive } \\
\text { tissue }\end{array}$ & $\begin{array}{c}\text { No. of tissue } \\
\text { samples screened } \\
(\mathrm{n}=853)\end{array}$ & $\begin{array}{l}\text { No. of CeMV } \\
\text { detections } \\
(\mathrm{n}=35)\end{array}$ & $\begin{array}{c}\text { Positive } \\
\text { diagnostic } \\
\text { cases }(\%)^{\mathrm{a}}\end{array}$ \\
\hline Lymph node & 47 & 13 & 5 & 337 & 13 & 33 \\
\hline Brain & 55 & 13 & 6 & 115 & 8 & 40 \\
\hline Lung & 58 & 15 & 4 & 130 & 5 & 27 \\
\hline Liver & 59 & 15 & 4 & 69 & 4 & 27 \\
\hline Spleen & 55 & 13 & 2 & 68 & 3 & 13 \\
\hline Kidney & 58 & 14 & 1 & 116 & 1 & 7 \\
\hline Skin & 3 & 3 & 0 & 3 & 0 & 0 \\
\hline Blubber & 3 & 3 & 0 & 3 & 0 & 0 \\
\hline Muscle & 2 & 1 & 0 & 3 & 0 & 0 \\
\hline Uterus & 1 & 1 & 0 & 1 & 0 & 0 \\
\hline Ovary & 1 & 1 & 0 & 2 & 0 & 0 \\
\hline Blood & 5 & 2 & 1 & 5 & 1 & 7 \\
\hline Amniotic fluid & 1 & 1 & 0 & 1 & 0 & 0 \\
\hline
\end{tabular}


Table 4. P-gene percent nucleotide identities among the Hawaiian cetacean morbillivirus (CeMV) isolates and other distinct CeMV strains/isolates. DMV: dolphin morbillivirus; PWMV: pilot whale morbillivirus; SWAt: Southwest Atlantic Brazilian regional isolate; Swan River: Swan River, Australia regional isolate; BWMV: beaked whale morbillivirus

\begin{tabular}{|c|c|c|c|c|c|c|}
\hline & GenBank acc. no. & DMV & PWMV & SWAt & Swan River & BWMV \\
\hline DMV P-gene & AJ608288 & - & & & & \\
\hline PWMV P-gene & AF200817 & 88.4 & - & & & \\
\hline SWAt (Brazilian) CeMV P-gene & KF711855 & 75.9 & 75.9 & - & & \\
\hline Swan River (Australian) CeMV P-gene & N/A & 75.9 & 75.9 & 100.0 & - & \\
\hline 15063-001 (Humpback whale) & KM460046 & 83.8 & 82.4 & 72.7 & 72.7 & 100.0 \\
\hline 15320-001 (Pygmy sperm whale) & KM460047 & 83.8 & 82.4 & 72.7 & 72.7 & 100.0 \\
\hline 15487-001 (Spinner dolphin) & KM460048 & 83.3 & 81.9 & 72.2 & 72.2 & 99.5 \\
\hline KW2008008 (Cuvier's beaked whale) & KM460049 & 83.8 & 82.4 & 72.7 & 72.7 & 100.0 \\
\hline KW2009004 (Spinner dolphin) & KM460050 & 82.9 & 81.9 & 72.2 & 72.2 & 99.1 \\
\hline KW2010005 (Longman's beaked whale) & KM460045 & 83.8 & 82.4 & 72.7 & 72.7 & - \\
\hline KW2010008 (Striped dolphin) & KM460051 & 83.8 & 82.4 & 72.7 & 72.7 & 100.0 \\
\hline KW2010012 (Blainville's beaked whale) & KM460052 & 83.8 & 82.4 & 72.7 & 72.7 & 100.0 \\
\hline KW2011001 (Bottlenose dolphin) & KM975649 & 81.9 & 80.6 & 70.8 & 70.8 & 98.1 \\
\hline KW2011008 (Sperm whale) & KJ482570 & 83.3 & 81.9 & 72.2 & 72.2 & 99.5 \\
\hline KW2011021 (Rough-toothed dolphin) & KM460053 & 83.8 & 82.4 & 72.7 & 72.7 & 100.0 \\
\hline KW2013015 (Spinner dolphin) & KM975648 & 83.8 & 82.4 & 72.7 & 72.7 & 100.0 \\
\hline KW2013023 (Risso's dolphin) & KM460054 & 83.8 & 82.4 & 72.7 & 72.7 & 100.0 \\
\hline KW2014006 (Striped dolphin) & KM460055 & 83.8 & 82.4 & 72.7 & 72.7 & 100.0 \\
\hline
\end{tabular}

Bank acc. no. KM460045) was used for all further comparisons to known strains/isolates (Fig. 2).

Using the BLAST N GenBank algorithm and Mac Vector 12.5 ClustalW sequence comparison algorithm, we determined that BWMV was $85.6 \%$ similar to DMV. Because of limited sequence information for PMV and PWMV, the full length of this sequence could only be compared to DMV. In the 378 bp region of comparable P-gene sequence, the BWMV consensus sequence was 87.6 and $85.7 \%$ similar to DMV and PWMV, respectively (Figs. 2 \& 3). BWMV was also compared to the 2 new regional isolates from Brazil (SWAt; Groch et al. 2014) and Australia (Swan River; Stephens et al. 2014). Nucleotide similarities based on $216 \mathrm{bp}$ of P-gene sequence ranged from 70.8 to $72.7 \%$ for both regional isolates (Figs. $2 \& 3$ ). The $1139 \mathrm{bp}$ of the BWMV N-gene sequence was then compared to the previously known CeMV strains DMV, PWMV, and PMV (Figs. 2 \& 3). Using a $230 \mathrm{bp}$ sequence common to all, the BWMV N-gene nucleotide sequence was 87.8, 88.7, and $83.9 \%$ similar to DMV, PMV, and PWMV, respectively. The BWMV N-gene was also $72.7 \%$ identical to a 188 bp partial sequence from the Swan River isolate. Phylogenetic analysis of both $\mathrm{N}$ - and P-genes using CDV as an outgroup indicated that BWMV clustered with the known strains DMV, PMV, and PWMV while the Swan River and SWAt isolates were distinct (Fig. 3).

\section{Heterogeneity of CeMV}

The overall detection rate for all 3 lymph nodes that were tested was $27 \%$. However, the detection rate varied substantially between lymph nodes: $25 \%$ for KW2010012 (Blainville's beaked whale) anal lymph; $2 \%$ for KW2010012 (Blainville's beaked whale) mediastinal lymph; and 61\% for KW2011021 (roughtoothed dolphin) anal lymph.

The overall detection rate was higher in the inner sub-samples $(32 \%)$ compared to the outer subsamples $(26 \%)$. The outer sample detection rates were $10 \%$ for Blainville's beaked whale anal lymph, $0 \%$ for Blainville's beaked whale mediastinal lymph, and $56 \%$ for rough-toothed dolphin anal lymph. The inner sample detection rates were $100 \%$ for Blainville's beaked whale anal lymph, $6 \%$ for Blainville's beaked whale mediastinal lymph, and $100 \%$ for rough-toothed dolphin anal lymph.

\section{DISCUSSION}

Since the initial report of a potentially unique isolate of CeMV in the Longman's beaked whale (West et al. 2013), our detailed analysis of the P- and Ngene regions of the Hawaiian CeMV isolates strongly suggest that the isolates from this study are from a new, previously uncharacterized strain of CeMV. As of this study, this BWMV was isolated from 12 differ- 


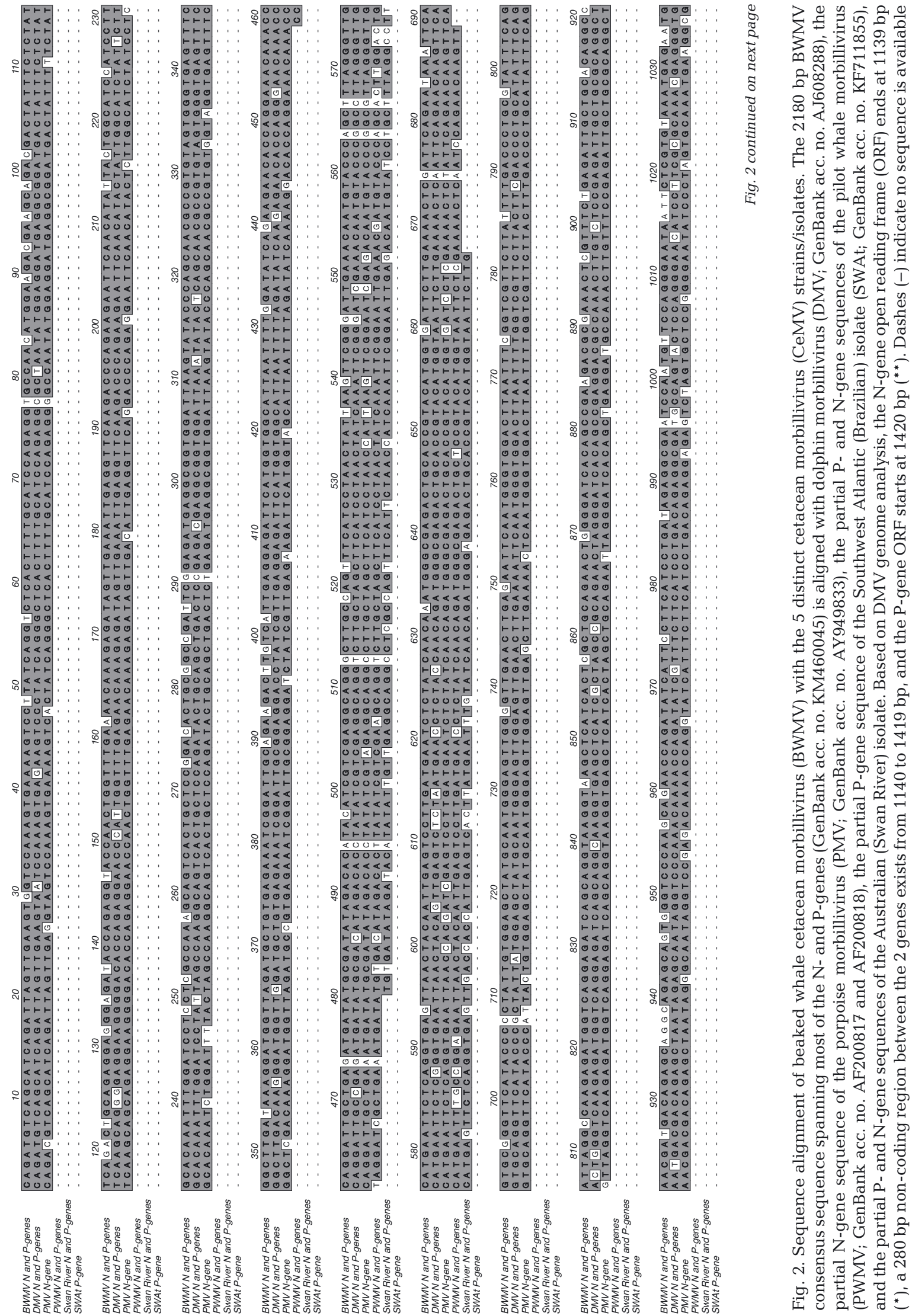




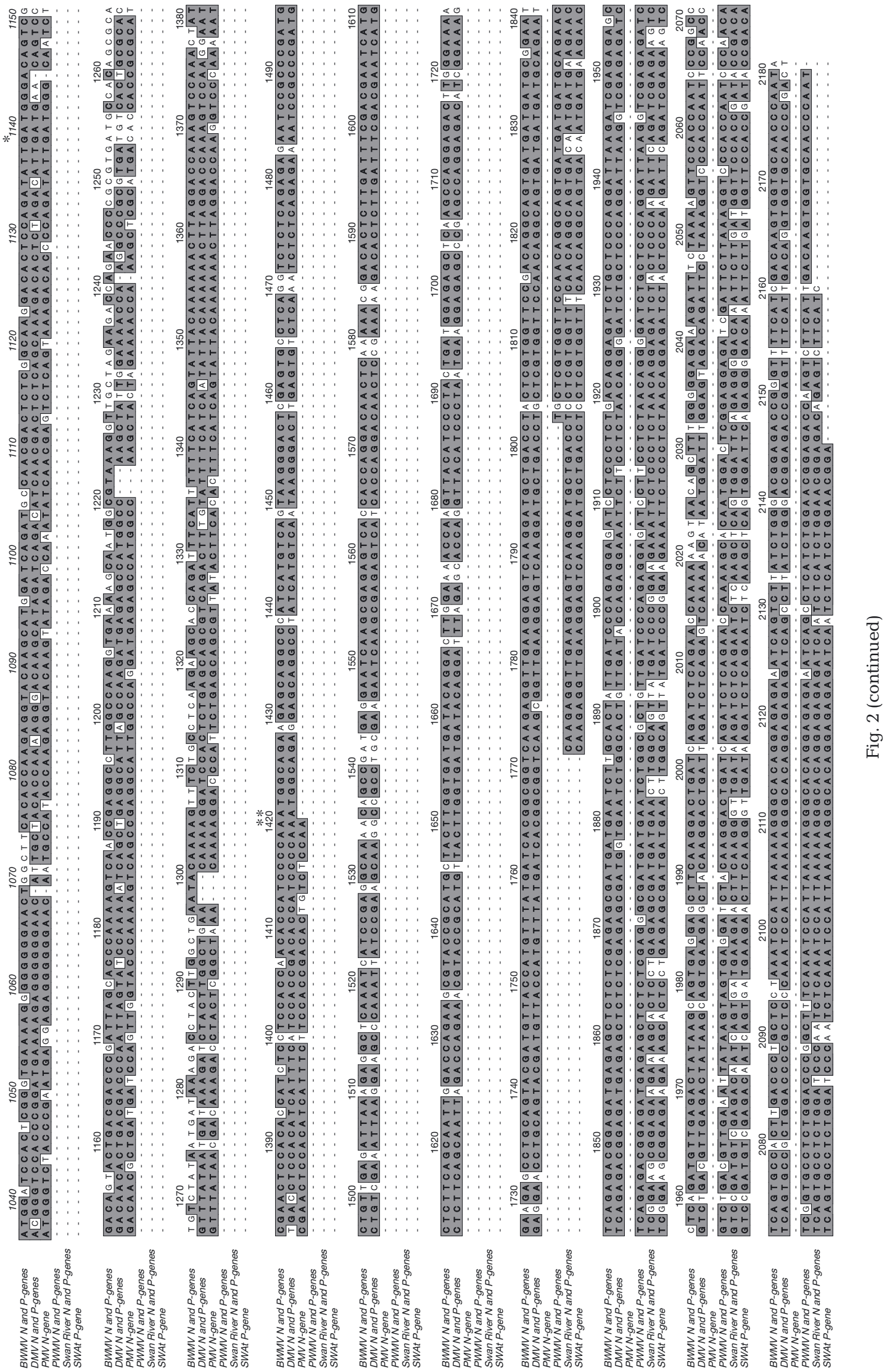




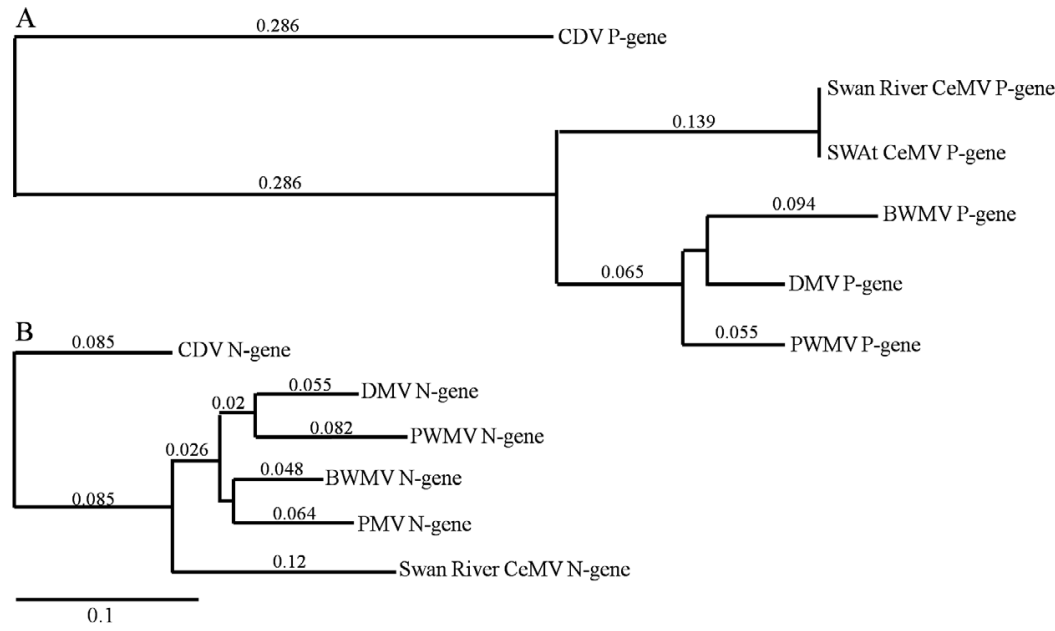

Fig. 3. Phylogenetic analysis of cetacean morbillivirus (CeMV) partial P- and $\mathrm{N}$-genes. Neighbor-joining, best fit trees show percent nucleotide identity among beaked whale morbillivirus (BWMV; GenBank acc. no. KM460045), dolphin morbillivirus (DMV; GenBank acc. no. AJ608288), porpoise morbillivirus (PMV; GenBank acc. no. AY949833), pilot whale morbillivirus (PWMV; GenBank acc. no. AF200817 and AF200818), Southwest Atlantic (Brazilian) isolate (SWAt; GenBank acc. no. KF711855), Australian Swan River isolate, and canine distemper virus (CDV; GenBank acc. no. NC_001921) as the outgroup. Trees were constructed using ClustalW within Mac Vector 12.5 software. A value of 0.1 is equal to a $10 \%$ nucleotide difference between 2 branches. (A) P-gene nucleotide similarity based on $343 \mathrm{bp}$ of common sequence (PMV P-gene sequence not available); (B) N-gene nucleotide similarity based on $188 \mathrm{bp}$ of common sequence (Brazilian SWAt N-gene sequence not available)

ent species and 15 individuals, and is the longest characterized CeMV sequence in the literature to date with the exception of DMV, whose genome has been fully sequenced.

The full $2180 \mathrm{bp}$ segment that includes a putative non-coding sequence between the N- and P-genes is 85.6\% similar to DMV. When comparing the relatively conserved P-gene, the BWMV P-gene is more distinct from DMV $(87.6 \%)$ and PWMV (85.7\%) than the DMV and PWMV strains are distinct (89.9\%) from each other. The N-gene is generally less conserved than the P-gene, and it is often used to help confirm which strain of CeMV is present in a population (Blixenkrone-Møller et al. 1994, Rima et al. 1995). Similar to the P-gene, the BWMV N-gene is as distinct from DMV (87.8\%), PMV (88.7\%), and PWMV $(83.9 \%)$ as these strains are distinct from each other since the DMV N-gene is 89.1 and $87.8 \%$ similar to PMV and PWMV, while PMV and PWMV are $85.7 \%$ similar to each other. Neighbor-joining trees of both the P- and N-genes also indicated that BWMV clusters with DMV, PWMV, and PMV, while the newly described Brazilian SWAt isolate and Australian Swan River isolate are distinct. Taken together, these results support the hypothesis that
BWMV is a novel strain of CeMV present in Hawaiian cetaceans.

BWMV is 1 of 3 potentially new regional strains/isolates recently identified. The SWAt isolate was identified by a 374 bp region of the P-gene in a Guiana dolphin Sotalia guianensis that stranded in Brazil in 2010 (Groch et al. 2014), while the Swan River isolate was identified by a 188 bp region of the $\mathrm{N}$-gene and a $390 \mathrm{bp}$ region of the P-gene in 2 Indo-Pacific bottlenose dolphins Tursiops aduncus that stranded in Western Australia in 2009 (Stephens et al. 2014). BWMV seems to be more closely related to the DMV strain, whereas the new Brazil and Australian isolates may represent a new clade (Fig. 3; Van Bressem et al. 2014). So far, the geographic distribution of the newly identified isolates is not known, while DMV and PMV seem to be more widely distributed and have been found in both the Atlantic and Pacific Oceans.

The incomplete timeline of CeMV cases is also emerging as archived tissues are examined retrospectively. PMV occurred almost simultaneously on both sides of the Atlantic Ocean around 1988. PMV and DMV caused similar epizootics on both sides of the Atlantic Ocean and Mediterranean Sea between 1990 and 1994. Between 1995 and 2000, 4 different strains (PMV, DMV, PWMV, and BWMV) occurred in both the Pacific and Atlantic Oceans as well as the Mediterranean Sea region. Since 2006, several isolated cases and a few epizootics, including one on the east coast of the USA beginning in 2013, have occurred throughout the Pacific and Atlantic Oceans (Barrett et al. 1995, Kennedy 1998, Di Guardo et al. 2005, Brown et al. 2014). Fig. S1 in the Supplement (www.int-res.com/articles/suppl/d117p215_supp.pdf) maps CeMV strains and outbreaks worldwide.

BWMV was detected in approximately one-fourth $(24 \%)$ of stranded Hawaiian cetaceans representing 11 different species of odontocetes and 1 mysticete (humpback whale). This level of detection in stranded animals is impressive considering the challenges associated with identifying morbillivirus in stranded cetaceans. Approximately $49 \%$ of animals that stranded in Hawai'i during the study period were not candidates for RNA-based testing because their condition was Code 3 or greater. Another chal- 
lenge in measuring CeMV occurrence that was revealed by this study is that BWMV is not evenly distributed in tissues. The overall BWMV detection rate, or the ability to accurately detect BWMV in lymph nodes, was $27 \%$. However, the detection rate varied widely (from 2 to $61 \%$ ) among individual lymph nodes. Sub-sampling from the interior may increase the likelihood of detecting CeMV (Jacob 2012).

Other studies have documented similar heterogeneity of morbillivirus distribution. Soto et al. (2011) used immunohistochemistry to study the brain in striped dolphins with localized central nervous system CeMV infections. The amount of staining was not homogenous throughout the brain; the axons and glial cells in the white brain matter and deeper neocortex layers stained darker than the surrounding areas (Soto et al. 2011). The detection rate within a particular tissue is probably affected by the severity and progression of the CeMV infection. Shin et al. (2004) noted variability in viral distribution among fluid compartments in a PCR analysis of blood, urine, saliva, and nasal discharge to determine detection rates of CDV in dogs. Detection rates varied, but were higher (56 to $82 \%$ ) with nested PCR than 1-step RT-PCR (20 to $50 \%$ ). The authors concluded that detection rates increase if multiple samples are used to test for CDV, and that nested PCR may increase the sensitivity of detecting CDV. They also concluded that CDV is not homogenously distributed among different sample types, and this may depend on the severity and progression of the CDV infection (Shin et al. 2004). Taken together, best practices for CeMV screening should include screening multiple tissues, sub-sampling multiple sections of tissue, utilizing as much tissue as possible, and thoroughly homogenizing tissues prior to PCR testing.

Whereas the first confirmed case of CeMV in stranded Hawaiian cetaceans was reported in a Longman's beaked whale in 2010 (West et al. 2013), our study revealed that this was not actually the first case of CeMV in Hawai'i. A complete survey of a cetacean archive that dates back to 1997 revealed that a humpback whale (15063) which stranded on Maui in 1998 was in fact the earliest confirmed occurrence of BWMV. Our results showed that BWMV has been present in ca. 1 animal $\mathrm{yr}^{-1}$ since 1998, excluding years where samples were not available. Although BWMV was not detected between 2002 and 2007, this gap is likely due to a lack of samples, since only 1 animal was available and appropriate for screening from this time period. Only a small number of animals $(n=8)$ were available for screening between 1997 and
2001, but the number of tissues available from each animal was generally less than what was obtained for animals that stranded after 2006. Since the HPU Marine Mammal Stranding program began in 2006, stranding response effort has increased significantly, such that many more fresh animals ( $\mathrm{n}=4$ to 13 Code 1 and 2 in a given year) were available to be screened for CeMV between 2008 and 2014.

Vertical transmission of CeMV has been proposed and is well supported by the presence of CeMV in a young striped dolphin (Di Guardo et al. 2010), a longfinned pilot whale fetus (Fernández et al. 2008), and a neonate sperm whale from Hawai'i (West et al. 2015). In addition, in our study BWMV was detected in a humpback whale calf (15063) that had fragments of the umbilicus still present during the initial necropsy, and 2 spinner dolphin calves (KW2009004 and KW2013015), one of which was suspected to be approximately 1 wk old. While these cases provide further evidence for vertical transmission, lateral transmission is also very important, as animals create and modify social groups and exchange bodily fluids (Di Guardo et al. 2010).

Important questions remain regarding CeMV disease progression. Interestingly, BWMV was detected in numerous tissues in the 3 Hawaiian beaked whales from this study, suggesting a systemic, or clinical (apparent), BWMV infection. This is supported by the pathology observed, including lymphoid depletion, encephalitis, and a possible secondary herpes virus infection in the Longman's beaked whale, as well as hypercellularity in lymph nodes of the Blainville's beaked whale (West et al. 2013). In the other 9 cetacean species, BWMV was identified in 1 or 2 tissues. Further histopathological analysis may reveal whether CeMV was less advanced in these individuals. In the Mediterranean, Soto et al. (2011) observed 2 different types of CeMV outbreaks in striped dolphins. During the initial epizootic in 2006-2007, an acute, systemic DMV infection killed hundreds of dolphins. Following the initial outbreak, striped dolphins that stranded between 2008 and 2010 were described as having chronic DMV infections that were localized to the central nervous system. These results were similar to findings seen in the largest CeMV epizootic that occurred in the Mediterranean Sea in 1990 (Domingo et al. 1995). Fewer animals died because of the localized DMV outbreak, suggesting that the second outbreak was not as lethal to the populations as the first (Soto et al. 2011). In this scenario, it is not possible to discern whether the acute versus chronic infection represented a change in viral virulence or a change in the 
immune status of the population. Extrapolating to BWMV, there is (as yet) no evidence of genetic variability among isolates from the various cetacean species to suggest differences in viral virulence. A more likely hypothesis may be that beaked whales, with their solitary nature and large home ranges, represent an immunologically naïve population, thus making beaked whale individuals more likely to succumb to BWMV.

In summary, this study revealed that a previously unknown strain of CeMV, BWMV, has been present in stranded Hawaiian cetaceans at least since 1998 and continues to persist today, affecting one-fourth $(24 \%)$ of stranded Hawaiian cetaceans and 12 different species. In contrast to recently characterized isolates from Brazil and Australia that may represent a distinct clade, BWMV appears to be more closely related to the previously known strains of CeMV (DMV, PMV, and PWMV). Further research is needed to understand the virulence, mode of transmission, and lethality of this novel CeMV strain and its impact on cetacean populations in the Pacific.

Acknowledgements. We thank Jianning Wang of the Australian Animal Health Laboratory for generously providing the Swan River N- and P-gene sequences. We also thank the HPU Marine Mammal Stranding Team volunteers, the Hawai'i Stranding Response Network volunteers, Hannah Tsunemoto for laboratory assistance, and anonymous experts that contributed valuable interpretations and advice. This work was funded by the NOAA Prescott Grant Program and the Hawai'i Pacific University Trustee's Endeavors Program.

\section{LITERATURE CITED}

Barrett T, Visser IKG, Mamaev L, Goatley L, Van Bressem MF, Osterhaus ADME (1993) Dolphin and porpoise morbilliviruses are genetically distinct from phocine distemper virus. Virology 193:1010-1012

Barrett T, Blixenkrone-Møller M, Di Guardo G, Domingo M and others (1995) Morbilliviruses in aquatic mammals: report on round table discussion. Vet Microbiol 44:261-265

Bellière EN, Esperón F, Fernández A, Arbelo M, Muñoz MJ, Sáncez-Vizcaíno JM (2011a) Phylogenetic analysis of a new cetacean morbillivirus from a short-finned pilot whale stranded in the Canary Islands. Res Vet Sci 90: 324-328

Bellière EN, Esperón F, Sánchez-Vizcaíno JM (2011b) Genetic comparison among dolphin morbillivirus in the 1990-1992 and 2006-2008 Mediterranean outbreaks. Infect Genet Evol 11:1913-1920

Blixenkrone-Møller M, Bolt G, Gottschalck E, Kenter M (1994) Comparative analysis of the gene encoding the nucleocapsid protein of dolphin morbillivirus reveals its distant evolutionary relationship to measles virus and ruminant morbilliviruses. J Gen Virol 75:2829-2834

Bolt G, Alexandersen S, Blixenkrone-Møller M (1995) The phosphoprotein gene of a dolphin morbillivirus isolate exhibits genomic variation at the editing site. J Gen Virol 76:3051-3058

- Bossart GD, Reif JS, Schaefer AM, Goldstein J, Fair PA, Saliki JT (2010) Morbillivirus infection in free-ranging Atlantic bottlenose dolphins (Tursiops truncatus) from the southeastern United States: seropidemiologic and pathologic evidence of subclinical infection. Vet Microbiol 143:160-166

Brown LC, Sheckler NK, Henriquez RN, Freitas JR and others (2014) Characterization of the 2013 mid-Atlantic bottlenose dolphin morbillivirus epizootic. In: Proc Merial-NIH National Veterinary Scholars Symposium. 31 Jul-3 Aug 2013, Cornell University, Ithaca, NY, p 92 (Abstract)

Casalone C, Mazzariol S, Pautasso A, Di Guardo G and others (2014) Cetacean strandings in Italy: an unusual mortality event along the Tyrrhenian Sea coast in 2013. Dis Aquat Org 109:81-86

Diallo A, Barrett T, Barbron M, Meyer G, Lefevre PC (1994) Cloning of the nucleocapsid protein gene of peste-despetits-ruminants virus: relationship to other morbilliviruses. J Gen Virol 75:233-237

> Di Guardo G, Marruchella G, Agrimi U, Kennedy S (2005) Morbillivirus infections in aquatic mammals: a brief overview. J Vet Med A Physiol Pathol Clin Med 52:88-93

Di Guardo G, Cocumelli C, Scholl F, Di Francesco CE, Speranza R, Pennelli M, Eleni C (2010) Chronic morbilliviral encephalitis in a young striped dolphin from Italy. Nat Prec, http://hdl.handle.net/10101/npre.2010.4912.1

> Domingo M, Vilafranca M, Visa J, Prats N, Trudgett A, Visser I (1995) Evidence for chronic morbillivirus infection in the Mediterranean striped dolphin (Stenella coeruleoalba). Vet Microbiol 44:229-239

Fernández A, Esperón F, Herraéz P, De Los Monteros AE and others (2008) Morbillivirus and pilot whale deaths, Mediterranean Sea. Emerg Infect Dis 14:792-794

Geraci JR, Lounsbury VJ (1993) Marine mammals ashore: a field guide for strandings. Texas A\&M University Sea Grant College Program, Galveston, TX

> Groch KR, Colosio AC, Marcondes MCC, Zucca D and others (2014) Novel cetacean morbillivirus in Guiana dolphin, Brazil. Emerg Infect Dis 20:511-513

Jacob JM (2012) Screening and characterization of morbillivirus in Hawaiian cetaceans. MSc thesis, Hawai'i Pacific University, Kaneohe, HI

Jensen B (2000) Characterization of the aryl hydrocarbon receptor from a cetacean: an approach for assessing contaminant susceptibility in protected species. PhD dissertation, Massachusetts Institute of Technology and Woods Hole Oceanographic Institution, Woods Hole, MA

Katayama Y, Kohso K, Nishimura A, Tatsuno Y, Homma M, Hotta H (1998) Detection of measles virus mRNA from autopsied human tissues. J Clin Microbiol 36:299-301

Kennedy S (1998) Morbillivirus infections in aquatic mammals. J Comp Pathol 119:201-225

Kennedy S, Smyth JA, Cush PF, McCullough SJ, Allan GM, Mcquaid S (1988) Viral distemper now found in porpoises. Nature 336:21

Krafft A, Lichy JH, Lipscomb TP, Klaunberg BA, Kennedy S, Taubenberger JK (1995) Postmortem diagnosis of morbillivirus infection in bottlenose dolphins (Tursiops truncatus) in the Atlantic and Gulf of Mexico epizootics by polymerase chain reaction-based assay. J Wildl Dis 31: $410-415$

Lipscomb TP, Schulman FY, Moffett D, Kennedy S (1994) 
Morbilliviral disease in Atlantic bottlenose dolphins (Tursiops truncatus) from the 1987-1988 epizootic. J Wildl Dis 30:567-571

Masek T, Vopalensky V, Suchomelova P, Pospisek M (2005) Denaturing RNA electrophoresis in TAE agarose gels. Anal Biochem 336:46-50

Reidarson TH, McBain J, House C, King DP and others (1998) Morbillivirus infection in stranded common dolphins from the Pacific Ocean. J Wildl Dis 34:771-776

Rima BK, Washaupt RGA, Welsh MJ, Earle JAP (1995) The evolution of morbilliviruses: a comparison of nucleocapsid gene sequences including a porpoise morbillivirus. Vet Microbiol 44:127-134

Shin YJ, Cho KO, Cho HS, Kang SK and others (2004) Comparison of one-step RT-PCR and a nested PCR for the detection of canine distemper virus in clinical samples. Aust Vet J 82:83-86

Soto S, Alba A, Ganges L, Vidal E and others (2011) Postepizootic chronic dolphin morbillivirus infection in Mediterranean striped dolphins Stenella coeruleoalba. Dis Aquat Org 96:187-194

Stephens N, Duignan PJ, Wang J, Bingham J and others (2014) Cetacean morbillivirus in coastal Indo-Pacific bottlenose dolphins, Western Australia. Emerg Infect Dis 20: 666-670

Taubenberger JK, Tsai M, Krafft AE, Lichy JH, Reid AH, Schulman FY, Lipscomb TP (1996) Two morbilliviruses implicated in bottlenose dolphin epizootics. Emerg Infect Dis 2:213-216

Editorial responsibility: Michael Moore, Woods Hole, Massachusetts, USA
Taubenberger JK, Tasi MM, Atkin TJ, Fanning TG and others (2000) Molecular genetic evidence of a novel morbillivirus in a long-finned pilot whale (Globicephalus melas). Emerg Infect Dis 6:42-45

> Uchida K, Muranaka M, Horri Y, Murakami N, Yamaguchi R, Tateyama S (1999) Non-purulent meningoencephalomyelitis of a Pacific striped dolphin (Lagenorhynchus obliquidens). The first evidence of morbillivirus infection in a dolphin at the Pacific Ocean around Japan. J Vet Med Sci 61:159-162

Van Bressem MF, Duignan PJ, Banyard A, Barbieri M and others (2014) Cetacean morbillivirus: current knowledge and future directions. Viruses 6:5145-5181

van de Bildt MWG, Kuiken T, Osterhaus ADME (2005) Cetacean morbilliviruses are phylogenetically divergent. Arch Virol 150:577-583

> Visser IKG, Van Bressem MF, De Swart RL, Van De Bildt MWG and others (1993) Characterization of morbilliviruses isolated from dolphins and porpoises in Europe. J Gen Virol 74:631-641

West KL, Sanchez S, Rotstein D, Robertson KM and others (2013) A Longman's beaked whale (Indopacetus pacificus) strands in Maui, Hawai'i, with first case of morbillivirus in the central Pacific. Mar Mamm Sci 29: 767-776

West KL, Levine G, Jacob J, Jensen B, Sanchez S, Colegrove $\mathrm{K}$, Rotstein D (2015) Co-infection and vertical transmission of brucella and morbillivirus in a neonatal sperm whale. J Wildl Dis 51:227-232

Submitted: January 28, 2015; Accepted: October 20, 2015 Proofs received from author(s): December 9, 2015 